\title{
THE EFFECT OF TEMPERATURE ON THE PROPERTIES OF FRESH SELF-COMPACTING CONCRETE
}

\author{
G. CYGAN ${ }^{1}$, J. GOLASZEWSKI ${ }^{2}$, M. DREWNIOK ${ }^{3}$
}

\begin{abstract}
The rheological properties of self-compacting concrete are closely influenced by temperature and the time. Previous studies which aim was to research the effect of temperature on self-compacting concrete workability, showed that the behaviour of fresh SCC at varying temperatures differs from that of normal vibrated concrete. The paper presents the study of rheological properties of fresh self-compacting concrete mixtures made with portland, blast furnace and component cement. Two types of superplasticizers were used. It was proven that temperature has a clear effect on workability; it can be reduced by selecting the appropriate superplasticizer and cement.
\end{abstract}

Keywords: self compacting concrete, workability, temperature, time

\section{INTRODUCTION}

The share of self-compacting concrete in the overall concrete production is not large. One of the reasons is a significant impact the temperature has on self-compacting concrete workability. Temperature is a factor inextricably linked to the processes of mixing and casting of concrete. The final temperature of the fresh concrete is influenced by a temperature of the components, ambient temperature, and the heat generated by the mixing. Ensuring the constant temperature is very problematic at the construction site. It is possible only during production of precast concrete. Influence of temperature on the workability of ordinary concrete is well recognized.

\footnotetext{
${ }^{1}$ Msc Eng., Silesian Technical University, Faculty of Civil Engineering, Akademicka 5 str. 44-100 Gliwice, Poland, e-mail: Grzegorz.Cygan@polsl.pl

${ }^{2} \mathrm{PhD}$. Associated Professor, Eng Silesian Technical University, Faculty of Civil Engineering, Akademicka 5 str. 44-100 Gliwice, Poland.

${ }^{3}$ Msc Eng.
} 
Increasing temperature leads to stiffening of the concrete mixtures. The loss of workability due to the increasing temperature does not disqualify concrete mix yet and correct casting is still possible. Workability loss can be compensated by the higher or longer mechanical vibration. In the case of self-compacting concrete, compaction process is due to the concrete's own weight. Load is caused by mixture's own weight, defeating the yield value, causing the flow of the mixture. The flow rate depends on the plastic viscosity. Increasing the plastic viscosity decreases the flow rate of the mixture. Gołaszewski and Cygan [1] showed that in some cases a significant lost of SCC workability may occur. In this case, the SCC mixture should be mechanically vibrated till it reaches adequate compaction (fig 1). Ghafoori and Diawara reached similar conclusions [2]. According to them, above a temperature of $20^{\circ} \mathrm{C}$, slump flow is declining with increasing temperature; this trend accelerates with rising temperature. According to Schmidt [3], it is possible to reduce undesirable temperature influence on SCC workability. It can be done by using suitably selected superplasticizers and other chemical admixtures.

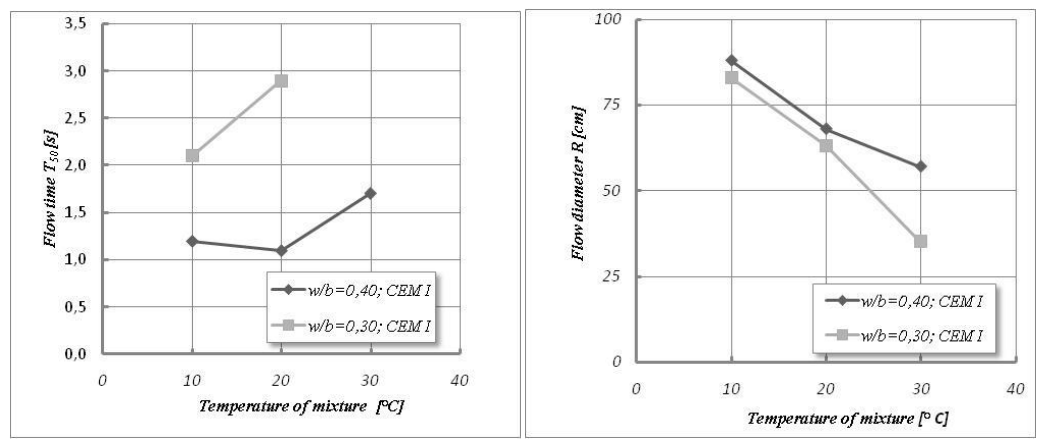

Fig. 1. Influence of temperature on flow diameter and flow time of self-compacting concretes.

\section{MATERIAL PROPERTIES AND COMPOSITION OF MIXTURES}

For-research were used three types of cement: CEM I 42,5 R, CEM III/42, $5 \mathrm{~N}$ - HSR/NA and CEM V/A(S-V) 32,5 R-LH and, two kinds of superplasticizers based on polycarboxylate ethers (both being new generation superplasticizers). First superplastizier caused good workability in time, high final strength with very low w/c ratio (for ready mix concrete, precast concrete and shotcrete). Second, caused high early and final strength for precast and prestressed concrete. The properties of materials and concrete composition are shown in table 1,2 and 3. 
Table 1. Characteristics of cement

\begin{tabular}{|c|c|c|c|c|c|c|c|c|}
\hline Cement & $\mathrm{SiO}_{2}$ & $\mathrm{CaO}$ & $\mathrm{Al}_{2} \mathrm{O}_{3}$ & $\mathrm{Fe}_{2} \mathrm{O}_{3}$ & $\mathrm{MgO}$ & $\mathrm{Na}_{2} \mathrm{O}_{\text {eq }}$ & $\mathrm{SO}_{3}$ & $\begin{array}{c}\text { Specific } \\
\text { surface } \\
{\left[\mathrm{m}^{2} / \mathrm{kg}\right]}\end{array}$ \\
\hline CEM I 42,5 R & 21,6 & 64,4 & 4,5 & 2,2 & 1,3 & 0,4 & 3,1 & 333 \\
\hline $\begin{array}{c}\text { CEM III/A 42,5N- } \\
\text { HSR/NA }\end{array}$ & 30,2 & 52,2 & 6,4 & 1,8 & 3,5 & 0,8 & 3,3 & 385 \\
\hline $\begin{array}{c}\text { CEM V/A 32,5 (S-V) R- } \\
\text { LH }\end{array}$ & 29,2 & 49,3 & 9,5 & 2,8 & 2,4 & 1,3 & 2,2 & 338 \\
\hline
\end{tabular}

Table 2. Basic properties of superplasticizers

\begin{tabular}{|c|c|c|c|}
\hline SP & Major constituent acc. producer & Density, $\left[\mathrm{g} / \mathrm{cm}^{3}\right]$ & Concentration, [\%] \\
\hline SP1 & carboxyl ether & 1,07 & 30,1 \\
\hline SP2 & carboxyl ether & 1,06 & 32,0 \\
\hline
\end{tabular}

Table 3. Compositions of SCC

\begin{tabular}{|c|c|c|c|c|c|c|c|c|}
\hline \multirow[b]{2}{*}{ Cement } & \multirow{2}{*}{$\begin{array}{l}\mathrm{w} / \mathrm{c} \\
\text { ratio }\end{array}$} & \multirow[b]{2}{*}{ Mixture } & \multirow{2}{*}{$\begin{array}{l}\text { Cement } \\
{\left[\mathrm{kg} / \mathrm{m}^{3}\right]}\end{array}$} & \multirow{2}{*}{$\begin{array}{l}\text { Water } \\
{\left[\mathrm{kg} / \mathrm{m}^{3}\right]}\end{array}$} & \multicolumn{2}{|c|}{ SP [\% m.c $]$} & \multirow{2}{*}{$\begin{array}{c}\text { Sand } \\
0-2 \mathrm{~mm}\end{array}$} & \multirow{2}{*}{$\begin{array}{c}\text { Coarse } \\
\text { aggregates } \\
2-8 \mathrm{~mm}\end{array}$} \\
\hline & & & & & SP1 & SP2 & & \\
\hline \multirow{2}{*}{ CEM I 42,5 R } & \multirow{6}{*}{0,3} & B1 & 572 & 172 & 3,0 & & \multirow{6}{*}{884} & \multirow{6}{*}{780} \\
\hline & & B2 & 580 & 175 & & 2,0 & & \\
\hline \multirow{2}{*}{$\begin{array}{c}\text { CEM III/A 42,5N- } \\
\text { HSR/NA }\end{array}$} & & B6 & 573 & 172 & 1,75 & & & \\
\hline & & B7 & 579 & 174 & & 1,00 & & \\
\hline \multirow{2}{*}{$\begin{array}{c}\text { CEM V/A } \\
\text { (S-V) } \\
32,5 \text { R- LH }\end{array}$} & & B11 & 555 & 167 & 2,50 & & & \\
\hline & & B12 & 559 & 168 & & 2,00 & & \\
\hline \multirow{2}{*}{ CEM I 42,5 R } & \multirow{6}{*}{0,4} & B16 & 508 & 203 & 1,0 & & \multirow{6}{*}{884} & \multirow{6}{*}{780} \\
\hline & & B17 & 510 & 204 & & 0,75 & & \\
\hline \multirow{2}{*}{$\begin{array}{c}\text { CEM III/A } 42,5 \mathrm{~N}- \\
\text { HSR/NA }\end{array}$} & & B21 & 502 & 201 & 0,75 & & & \\
\hline & & B22 & 504 & 202 & & 0,50 & & \\
\hline \multirow{2}{*}{$\begin{array}{c}\text { CEM V/A } \\
\text { (S-V) } \\
32,5 \text { R- LH }\end{array}$} & & B26 & 489 & 195 & 1,50 & & & \\
\hline & & B27 & 493 & 197 & & 0,75 & & \\
\hline
\end{tabular}

The rheological parameters of fresh concrete were determined using a rheometer Viskomat XL and described by the Bingham model. Parallel to the rheometric tests, were performed technical tests according to PN-EN 12350-2, PN-EN 12350-8. To archive a suitable temperature, all ingredients were either heated or cooled. Weighed portions of ingredients were stored at appropriate temperatures for about 24 hours. Laboratory room temperature was also kept at the proper level. Superplasticizer was dosed together with water, mixing time was 5 minutes. 


\section{THE RESULT AND DISCUSSION}

Figures 2,3 show the effect of temperature on workability of fresh concretes. After mixing, the yield stress $(\mathrm{g})$ is usually the lowest at $30^{\circ} \mathrm{C}$, and is the highest at $10^{\circ} \mathrm{C}$. During the time, at a temperature of 10 degrees Celcius workability clearly improves. This is evident in the case of all the tested cements, superplasticizers and w/c ratio. At temperatures of about 10 degrees concrete mixes must be longer mixed This observation is particularly important for precast concrete plants, because the readymix concrete is additionally mixed during transport. At temperatures under $20^{\circ} \mathrm{C}$, superplasticizer needs more time to effectively work. At 30 degrees, initially more fluid fresh concrete stiffens faster. This is more evident in the case of fresh concrete with $\mathrm{w} / \mathrm{c}=0,4$ ratio.

For concretes at $30^{\circ} \mathrm{C}$ the situation is reversed. Initially low yield point rapidly increases, mainly due to the progressive process of hydration, reducing the amount of free water and superplasticizer consumption. Plastic viscosity (h) usually decreases with increasing temperature. Therefore, fresh concrete at higher temperatures may be more susceptible to segregation. Differences in the effectiveness of superplasticizers in relation to test cements are due to the quantitative the relations between the phases of clinker. According to Yoshioka et al [4] the largest amount of superplasticizer are absorbed by ferrit and aluminate. The major reaction products formed during the early hydration are $\mathrm{Ca}(\mathrm{OH})_{2}, \mathrm{C}-\mathrm{S}-\mathrm{H}, \mathrm{AFm}$ and Aft phases. According to Plank and Hirsch [5], the adsorbed amount of superplasticizer strongly depends on the existence of a positive zeta potential of the hydration phase. Zeta potential of ettringite is very positive. Ettringite is able to adsorb high quantities of negatively charged superplasticizers. This causes more dispersion of the mixtures. At higher temperatures, more of ettringite was formed, so also at 30 degrees the mixtures are initially most fluid. 

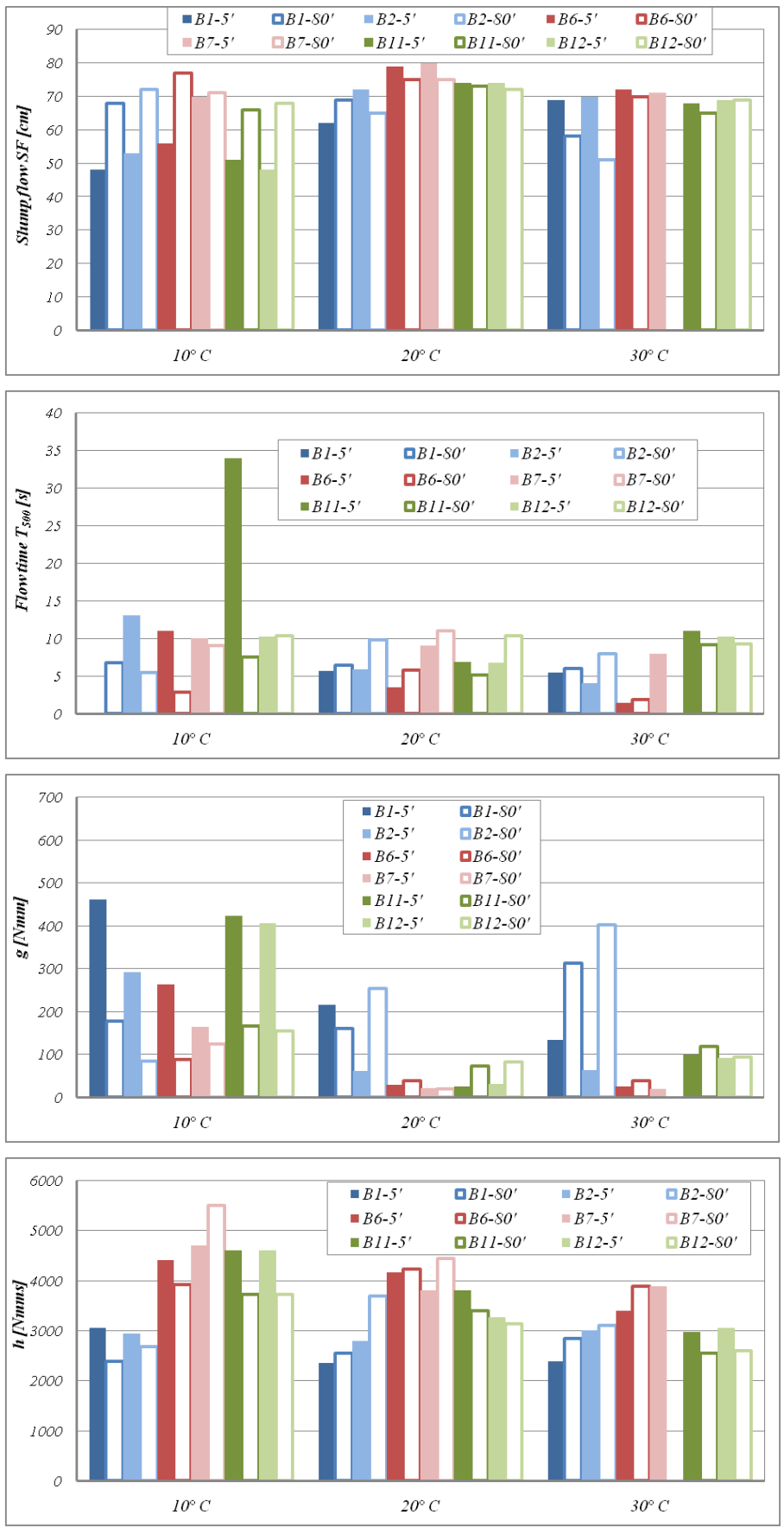

Fig.2. Effect of temperature on workability of self compacting concrete with w/c ratio 0,3. 

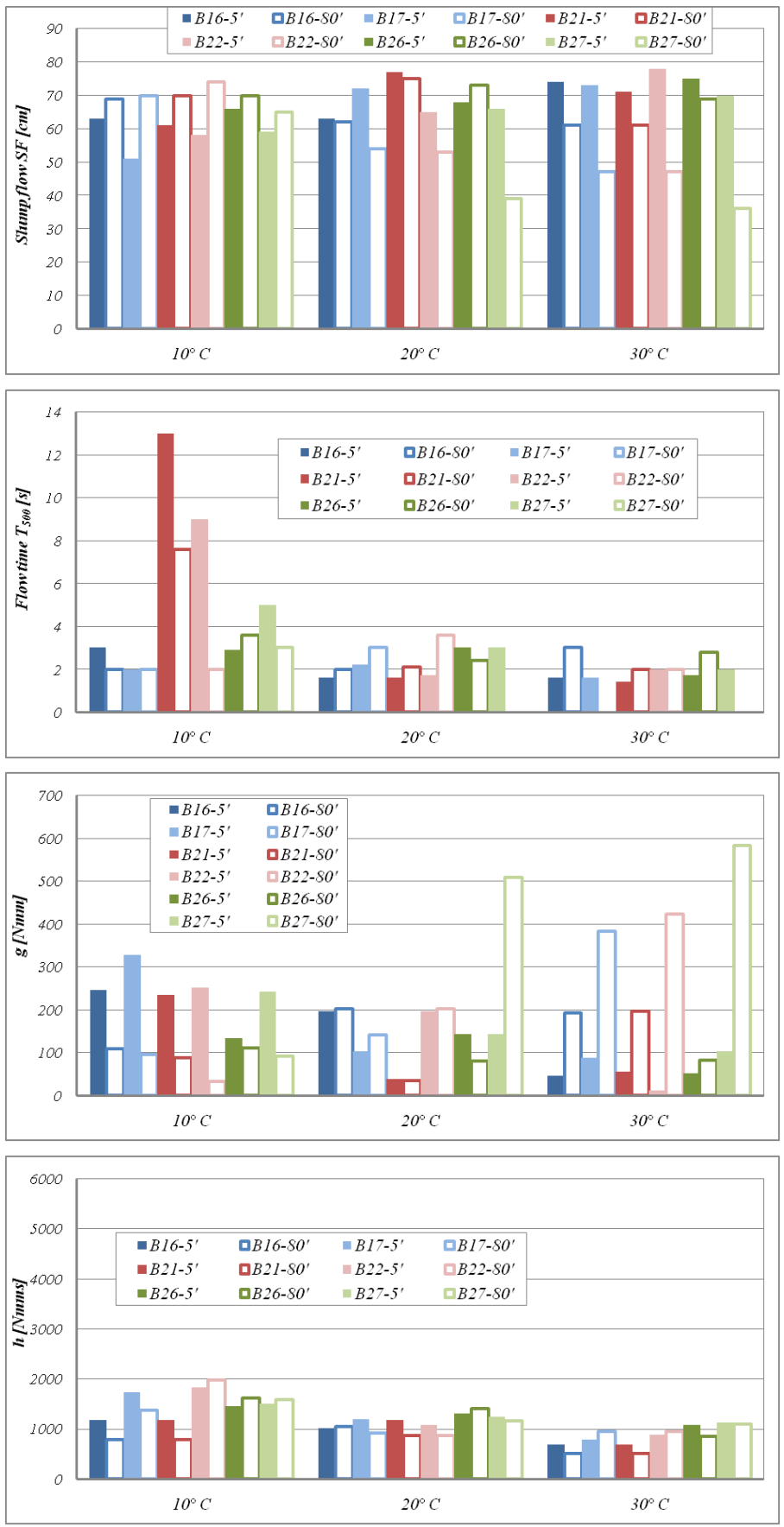

Fig.3. Effect of temperature on workability of self compacting concrete with w/c ratio 0,4 . 


\section{Conclusions}

The mechanism of the effect of temperature on rheological properties of self-compacting concrete mixtures is more complex than in the case of ordinary concrete. It is associated with dose and kind of superplasticizer and its temperature resistance in terms of workability. It is also associated with cement type and kind of superplasticizer.

There is an agreement with the compatibility of the superplasticizers and cements in the context of the temperature.

Effect of the temperature is associated with two opposing effects that occur in parallel. When the temperature increases, increases the speed of hydration, thereby causing deteriorating of the workability. On the other hand, the higher temperature causes producing the larger amounts of ettringite, which adsorbs superplasticizer. That effect is very desirable in connection with concrete flowability.

Superplasticizer's efficiency depends on temperature. It is visible especially in SCC consistency changing.

Superplasticizer SP 1, which was designed for ready mix concretes better maintains consistency in time, even at higher temperatures.

Appropriate choice of cement and superplasticizer may prevent the casting problems of fresh concrete, particularly in the case CEM III and SP 2.

at the lower temperature, the maximum effect of the flowability occurs later. 


\section{REFERENCES}

1. J. Gołaszewski, G.Cygan, Einfllus der temperature auf die Verarbeitbarkeit selbverdichtender Betonmischungen, BWI - Betonwerk International, pp. 40-46, 2009.

2. N. Ghafori , H. Diawara, Influence of temperature on fresh performance of self-consolidating concrete, Construction and Building Materials, vol.24, pp.946-955, 2010.

3. W. Schmidt, 2014, Design concepts for the robustness improvement of self-compacting concrete - Effects of admixtures and mixture components on the rheology and early hydration at varying temperatures, Eindhoven University of Technology, Bouwstenen nr193, the Netherlands, 2014.

4. K. Yoshioka, E.-I. Tazawa, K. Kawai, T. Enohata, Adsorption characteristics of superplasticizers on cement component minerals, Cement and Concrete Research,vol. 32 (2002) 1507-1513.

5. J. Plank, C. Hirsch, Impact of zeta potential of early cement hydration phases on superplasticizer adsorption, Cement and Concrete Research, vol 37,pp. 537-542,2007.

Received 14. 09. 2015

Revised 10.10.2015

\section{LIST OF FIGURES AND TABLES:}

Fig. 1. Influence of temperature on flow diameter and flow time of self compacting concretes.

Rys. 1. Wpływ temperatury na średnicę i czas płynięcia mieszanek betonów samozagęszczalnych.

Fig. 2. Effect of temperature on workability of self compacting concretes with $\mathrm{w} / \mathrm{c}$ ratio 0,3 .

Rys.2. Wpływ temperatury na urabialność mieszanek betonów samozagęszczalnych o w/c=0,3.

Fig. 3. Effect of temperature on workability of self compacting concretes with w/c ratio 0,4.

Rys.3. Wpływ temperatury na urabialność mieszanek betonów samozagęszczalnych o w/c=0,4.

Tab. 1. Characteristics of cements

Tab. 1. Właściwości cementów

Tab.2. Basic properties of superplasticizers

Tab.2. Podstawowe właściwości superplastyfikatorów

Tab.3. Compositions of SCC

Tab.3. Receptury mieszanek BSZ 


\section{WPLYW TEMPERATURY NA WLAŚCIWOŚCI MIESZANEK BETONÓW SAMOZAGĘSZCZALNYCH}

Stowa kluczowe: temperatura, urabialność, beton samozagęszczalny

\section{STRESZCZENIE:}

Udział mieszanek betonu samozagęszczalnego w ogólnej produkcji betonu towarowego, czy nawet w produkcji prefabrykatów nie jest duży. Pomimo korzyści jakie ta technologia za sobą niesie. Jednym z powodów jest znaczna wrażliwość właściwości reologicznych mieszanek na zmiany temperatury. Właściwości reologiczne - granica płynięcia g i lepkość plastyczna h odpowiadające średnicy rozpływu R i czasowi rozpływu T 500, pod wpływem zmian temperatury mogą się zmieniać tak, że mieszanka ulegnie segregacji bądź niemożliwy będzie proces jej samo zagęszczenia. Mechaniczne zagęszczanie mieszanki samozagęszczalnej, która straciła zdolność do samo zagęszczania, jest dopuszczalne ale musi być prowadzone z ostrożnością. W łatwy sposób można doprowadzić do przewibrowania i segregacji składników. Tym samym uzyskamy wadliwy beton o niejednorodnej strukturze.

W badaniach przedstawionych $\mathrm{w}$ artykule, określono wpływ temperatury na właściwości reologiczne mieszanek mierzone reometrem XL oraz na czas i średnicę rozpływu według PN-EN 12350-2, PN-EN 12350-8. Mieszanki betonu samozagęszczalnego o dwóch wielkościach w/c=0,3 i 0,4 wykonano z użyciem cementów: portlandzkiego, hutniczego i wieloskładnikowego. Zastosowano dwa rodzaje superplastyfikatorów polikarboksylowych. Pierwszy oznaczony symbolem SP 1 charakteryzujący się dobrym utrzymaniem efektu upłynnienia w czasie, stosowany głównie przy produkcji betonu towarowego, drugi SP 2 odpowiedni przy produkcji elementów prefabrykowanych. Mieszanki były wykonywane w ten sposób aby miały w chwili rozpoczęcia badań założone temperatury 10,20 i $30{ }^{\circ} \mathrm{C}$. Składniki schładzano bądź ogrzewano przez $24 \mathrm{~h}$ w odpowiednich temperaturach. Podczas badań temperatura mieszanki i pomieszczenia była utrzymywana na założonym poziomie. Właściwości reologiczne, średnice i czasy rozpływu, określono bezpośrednio po zakończeniu mieszania i po upływie 80 minut.

W przypadku badanych superplastyfikatorów i cementów widoczne jest, że efektywność domieszek zmniejsza się znacząco $\mathrm{w}$ temperaturach poniżej $20^{\circ} \mathrm{C}$. Jest to tendencja nie zależna od wielkości w/c, choć $\mathrm{w}$ przypadku w/c $=0,3$ efekt jest wyraźniejszy. W temperaturze $30{ }^{\circ} \mathrm{C}$ mieszanki początkowo charakteryzują się największymi średnicami rozpływu, co związane jest z większą adsorpcją superplastyfikatora na cząstkach cementu i produktach jego hydratacji. Im więcej zostanie zaadsorbowanego superplastyfikatora na produktach hydratacji tym większa zdolność superplastyfikatora do dyspergowania mieszanki. Szybciej przebiegający proces hydratacji sprawia jednak, że utrata urabialności szybciej postępuje wraz upływem czasu. Łańcuchy boczne zaadsorbowanego superplastyfikatora są przykrywane przez pojawiające się z czasem produkty hydratacji, tym samym maleje zdolność upłynniania mieszanki. Średnica rozpływu mieszanek wykonywanych w temperaturze $10{ }^{\circ} \mathrm{C}$, początkowo jest najmniejsza, ale wraz z upływem czasu ulega zwiększeniu. W niższych temperaturach proces hydratacji a w szczególności proces powstawania etryngitu, jest opóźniony. Etryngit z uwagi na swój wysoce dodatni potencjał $\zeta$ jest zdolny do adsorbowania znacznych ilości ujemnie naładowanego superplastyfikatora. Gdy w roztworze porowym zaczynu cementowego pojawi się odpowiednia ilość pól adsorpcji superplastyfikatora, związana między innymi z ilością etryngitu wzrasta efektywność superplastyfikatora, a tym samym średnica rozpływu mieszanek. Z praktycznego punktu widzenia należy zaznaczyć, że mieszanki wykonywane $\mathrm{w}$ temperaturach poniżej $15{ }^{\circ} \mathrm{C}$ wymagają dłuższego czasu wiązania po to by uzyskać zamierzony efekt upłynnienia. To spostrzeżenie jest szczególnie istotne w przypadku mieszanek wykorzystywanych w produkcji prefabrykatów. W przypadku mieszanek betonu towarowego, które są mieszane przez czas transportu 
betonowozem, maksymalny możliwy do uzyskania efekt upłynnienia, może przypadać na moment układania mieszanki w deskowaniu. Obsługa węzła betoniarskiego musi mieć świadomość tego typ zjawisk zachodzących w niższych temperaturach. Chęć uzyskania założonej konsystencji na węźle betoniarskim, poprzez zwiększenie ilości superplastyfikatora, może doprowadzić do mieszanki ulegającej segregacji na placu budowy.

Lepkość plastyczna, a tym samym czas rozpływu generalnie zmniejsza się wraz ze wzrostem temperatury. Mniejsza lepkość mieszanek w wyższych temperaturach może skutkować skłonnością mieszanek do segregacji.

Charakter, jak i wielkość zmian parametrów reologicznych mieszanek betonowych pod wpływem temperatury zależy od rodzaju cementu, rodzaju superplastyfikatora i stosunku w/c, nie pozwalając na uogólnienia. Jest to konsekwencją nakładających się zjawisk. Wraz ze zmianą temperatury zmienia się szybkość procesu hydratacji cementu (wzrost temperatury zwiększa szybkość procesu hydratacji przyczyniając się do szybszej utraty urabialności), zmianie ulega stopień adsorpcji superplastyfikatorów na ziarnach cementu i produktach jego hydratacji (stopień adsorpcji zwiększa się ze wzrostem temperatury, co z jednej strony początkowo zwiększa efekty działania superplastyfikatora, jednak w dłuższym czasie przyczynia się do szybszej utraty urabialności), zmianie ulega intensywność zjawisk międzyfazowych. Uogólnienie wpływu temperatury na właściwości mieszanek na spoiwach cementowych jest więc zagadnieniem trudnym, o ile w ogóle możliwym. O zachowaniu się danej mieszanki o określonych składnikach i proporcjach wnioskować można tylko na podstawie badań kontrolnych mieszanki. Dzięki którym otrzymamy pełną charakterystykę zmian jakim podlega mieszanka betonowa $\mathrm{w}$ prognozowanych warunkach wbudowania. Taki tok postępowania nie powinien dziwić, zwłaszcza w przypadku wykonywania odpowiedzialnych konstrukcji - mieszanka betonowa jest często „szyta na miarę” tak by spełniać określone wymagania. 